\title{
Utilization of Geothermal Water (Şanlıurfa-Karaali) Medium to Enhance DNA Protection and Phycocyanin in Spirulina platensis Production
}

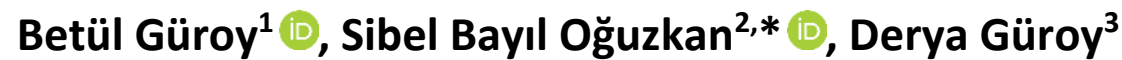

${ }^{1}$ Yalova University, Armutlu Vocational School, Food Processing Technology Department, Yalova, Turkey.

${ }^{2}$ Gaziantep University, Vocational School of Health Services, Department of Medical Services and Techniques, Gaziantep, Turkey.

${ }^{3}$ Yalova University, Armutlu Vocational School, Aquaculture Department, Yalova, Turkey.

\section{How to cite}

Güroy, D., Oğuzkan, S.B., Güroy, D., (2022). Utilization of geothermal water (Sanlıurfa-Karaali) medium to enhance DNA protection and phycocyanin in Spirulina platensis production. Aquaculture Studies, 22(3), AQUAST762. http://doi.org/10.4194/AQUAST762

\section{Article History}

Received 25 August 2021

Accepted 21 February 2022

First Online 23 February 2022

\section{Corresponding Author}

Tel.: +903423172188

E-mail: bayil@gantep.edu.tr

\section{Keywords}

Spirulina

Phycocyanin

Protein

Geothermal water

DNA

\begin{abstract}
Spirulina's industrial use depends on its sustainability and economic production. Geothermal water sources are well known potential water sources for Spirulina' slowcost production. This research aimed to study the effects on Arthrospira (Spirulina) platensis culture of Sanlıurfa (Karaali) geothermal water. Spirulina was cultured in a $2000 \mathrm{~mL}$ Erlenmeyer flask for three weeks. The Schlösser medium (SM) was substituted with $50 \%$ and $100 \%$ of the volume of the culture medium with the Sanlıurfa geothermal water. The results determined that 3.25 phycocyanin purity ratio $\left(A_{620} / A_{280}\right), 8 \%$ phycocyanin and $38.3 \%$ protein in the nutrient medium containing $50 \%$ Sanliurfa (Karaali) geothermal water. In the Schlösser Spirulina nutrient medium, defined as the control group, the protein content of $55 \%$ and a content of phycocyanin of $16.9 \%$ was achieved a phycocyanin purity ratio of 4.43 . Although the protein and phycocyanin ratios of Spirulina produced with geothermal water replaced are lower than in Schlösser medium, DNA protective activity of Spirulina produced in the geothermal water of Sanliurfa Karaali showed better protective activity than those produced in the Schlösser medium.
\end{abstract}

\section{Introduction}

Spirulina is a microalga systematized in the class of cyanobacteria called blue-green microalgae, containing high-value molecules such as essential amino acids, vitamins, minerals, essential oils, beta-carotene, phycocyanin, chlorophyll and other bioactive components. Spirulina is effectively produced in open ponds and photobioreactors. The production strategy affects Spirulina's cost and is produced at 3.8-9.59 €/ kg in outdoor pools. Spirulina production costs may increase up to 20 -fold in the photobioreactor system and range from 18.7 to $74.29 € / \mathrm{kg}$ (Delrue et al., 2017).
Although it is a preferred food in human nutrition, it is an expensive ingredient in the feed sector (Sugiharto et al., 2018). It is emphasized that Spirulina platensis, which has a significant health effect, inhibits inflammatory cells in the lungs and is beneficial to health (Xiong et al., 2018). Several kinds of research have been carried out that show that Spirulina-supplemented foods are richer in protein, fat and mineral content (Guroy, 2017; Lucas et al., 2018). It has also been reported that dietary Spirulina enhances disease resistance (Yuand et al., 2018; Lokapirnasaria et al., 2016) and prevents weight loss during starvation in fish (Guroy et al., 2011). Although it is an expensive 
ingredient in feeds, it is stated that even small amounts of Spirulina addition provide significant benefits (Mahmoud et al., 2018; Sugiharto et al., 2018).

Spirulina is an expensive product due to its high production cost, and research on Spirulina has focused on reducing Spirulina operating costs. The use of the different mediums as nutrients for algae production (Markou et al., 2018), the application of production strategies such as various light sources (Prates et al., 2018) and temperature change (de Jesus et al., 2016) have positive effects on low-cost algal production. Nutrient mediums formulated by Zarrouk (1966), Paoletti et al. (1975) and Schlösser (1994) are used to produce Spirulina in the world as they are sufficient in terms of micro and macronutrients. Since these nutrient media are generally expensive, alternative nutrient media that can be used instead of them are being investigated. Research conducted is often compared to these mediums (Pelizer \& Moraes, 2014). Since geothermal waters are similar mineral contents throughout the year, they can be considered an alternative nutrient medium. Geothermal water can be used directly or substitutable of these nutrient mediums depending on mineral content to achieve optimal algal productivity. In Turkey, two hundred twenty-seven geothermal areas are determined temperatures ranging from $20-287^{\circ} \mathrm{C}$ (Lund \& Boyd, 2016). Şanlıurfa (Karaali) geothermal water in the Southeastern Anatolia Region has a source water temperature of $48^{\circ} \mathrm{C}$ and $236.6 \mathrm{mg} . \mathrm{L}$ ${ }^{1}$ bicarbonate that it has content (Çiftçi, 2015).

One of the most important potential advantages of geothermal waters isto be veryrich in minerals to support When geothermal nutrients are used in Spirulina cultivation, the mineral structure of geothermal waters may cause the content of Spirulina nutrient levels and bioactive components to decrease or increase (Guroy \& Guroy, 2018; Bayil Oguzkan et al., 2018). This advantage and disadvantage of protein quantities can broaden the spectrum of economic use of Spirulina. The bioactive components in natural products could eliminate the harmful effects of free radicals on the cell with their antioxidant character. The hydroxyl and hydrogen peroxide radicals are the most influential radicals in metabolism. This radical can quickly attack nucleotides and cause permanent damage to the structure of DNA, which is the most critical genetic nucleotide (Gutteridge \& Halliwell, 2000). Therefore, it was also aimed to determine the oxidant status and DNA protective activities of Spirulina in this present study. In a previous study, Spirulina produced in Shössler medium showed antioxidant activity and had protective effects on DNA (Bayil Oguzkan et al., 2018). In this study, Şanlıurfa (Karaali) geothermal water in the Southeastern
Anatolia Region as a nutrient medium was investigated for the first time in Arthrospira (Spirulina) platensis cultivation.

\section{Material and Method}

\section{Geothermal Water and Spirulina mediums}

Şanlıurfa geothermal water was transported to Algal Production Unit of Yalova University with the support of Armutlu District Governorship of Yalova and Haliliye Municipality of Şanlıurfa. Schlösser medium (Schlösser, 1994), containing the following nutrients (g.L $\left.{ }^{-1}\right)$ : $13.61\left(\mathrm{NaHCO}_{3}\right) ; 4.03\left(\mathrm{Na}_{2} \mathrm{CO}_{3}\right) ; 0.5\left(\mathrm{~K}_{2} \mathrm{HPO}_{4}\right)$; $2.50\left(\mathrm{NaNO}_{3}\right) ; 1\left(\mathrm{~K}_{2} \mathrm{SO}_{4}\right) ; 1(\mathrm{NaCl}) ; 0.20\left(\mathrm{MgSO}_{4} .7 \mathrm{H}_{2} \mathrm{O}\right)$; $0.04 \quad\left(\mathrm{CaCl}_{2} .2 \mathrm{H}_{2} \mathrm{O}\right) ; \quad 0.01 \quad\left(\mathrm{FeSO}_{4} .7 \mathrm{H}_{2} \mathrm{O}\right) ; \quad 0.08$ ( $\mathrm{Na}_{2}$ EDTA.2 $\left.\mathrm{H}_{2} \mathrm{O}\right)$. Trace metal solution was followed as; $2.15 \mu \mathrm{M}\left(\mathrm{Na}_{2} \mathrm{EDTA}\right) ; 2.52 \mu \mathrm{M}\left(\mathrm{FeSO}_{4} .7 \mathrm{H}_{2} \mathrm{O}\right) ; 8.97 \mathrm{nM}$ $\left(\mathrm{MnSO}_{4} \cdot 7 \mathrm{H}_{2} \mathrm{O}\right) ; 3.48 \mathrm{nM}\left(\mathrm{ZnSO}_{4} \cdot 7 \mathrm{H}_{2} \mathrm{O}\right) ; 0.162 \mu \mathrm{M}$ $\left(\mathrm{H}_{3} \mathrm{BO}_{3}\right) ; \quad 3.44 \quad \mathrm{nM} \quad\left(\mathrm{Co}\left(\mathrm{NO}_{3}\right)_{2} \cdot 6 \mathrm{H}_{2} \mathrm{O}\right) ; 4.13 \mathrm{nM}$ $\left(\mathrm{Na}_{2} \mathrm{MoO}_{4} \cdot 2 \mathrm{H}_{2} \mathrm{O}\right) ; 0.02 \mathrm{nM}\left(\mathrm{CuSO}_{4} \cdot 5 \mathrm{H}_{2} \mathrm{O}\right)$. All nutrients were dissolved in distilled water containing as according to Schlösser (1994).

In this study, bicarbonate values in nutrient media were taken into account. The bicarbonate content of the experimental groups is presented in Table 1.

\section{Culture Conditions of Spirulina (Arthrospira) platensis}

Spirulina (Arthrospira) platensis was obtained from the Algal Production Unit of Yalova University. Starting cultures were prepared by inoculating Spirulina platensis in Schlösser Spirulina medium (Schlösser, 1994) at $30^{\circ} \mathrm{C}$ under air feed and average 1000 lux illumination. The experiment was run with three replicates in a $2000 \mathrm{~mL}$ Erlenmeyer flask for three weeks. The groups were as follows.

Group 1: containing $1800 \mathrm{~mL}$ sterilized Schlösser medium, Group 2: containing $1800 \mathrm{~mL}$ geothermal medium, Group 3: containing $900 \mathrm{~mL}$ geothermal media and $900 \mathrm{~mL}$ Schlösser medium.

A starting culture containing $70 \times 10^{4}$ cells $/ \mathrm{mL}$ in a ratio of 1: $6(300 \mathrm{~mL})$ of the volume of the prepared nutrient medium was inoculated. At the beginning of the experiment, the groups were $8 \times 10^{4}$ cells $/ \mathrm{mL}$. The temperature $\left({ }^{\circ} \mathrm{C}\right), \mathrm{pH}$, optical density and cell counts of culture in the Erlenmeyer flask were measured every three days a week during the trial. All groups were inoculated with Spirulina platensis culture $(0.02 \mathrm{mg} / \mathrm{mL}$ $=$ initial optical density of 0.238 at absorbance $750 \mathrm{~nm}$ and the optical density read at $A_{750}$ (Lakshmanan et al., 2013). Algae cells were filled in the Neubauer counting

Table 1. The bicarbonate content of the experimental groups.

\begin{tabular}{ll}
\hline Spirulina Mediums & $\mathrm{HCO}_{3}(\mathrm{~g} / \mathrm{L})$ \\
\hline Schlösser medium $100 \%$ & 13.6 \\
Geothermal water $100 \%$ & 0.236 \\
Geothermal water $50 \%$ & 6.918 \\
\hline
\end{tabular}


chamber and covered with lamellae. Cells were counted under a microscope and calculated with the following expression (Radhakrishnan et al., 2017).

$$
\text { Cell } / \mathrm{mL}=\text { Total number of cells } / 10 \times 4 \times 10^{-6}
$$

At the end of cultivation, Spirulina biomass was dried after filtration from $45 \mu$ plankton mesh.

\section{Phycocyanin Analysis}

$40 \mathrm{mg}$ samples were placed in a $10 \mathrm{~mL}$ centrifuge tube containing $100 \mathrm{mM}$ phosphate buffer (10.64 $\mathrm{g} \mathrm{K}_{2} \mathrm{HPO}_{4}$ and $5.29 \mathrm{~g} \mathrm{KH}_{2} \mathrm{PO}_{4}$ per L, $10 \mathrm{~mL}, \mathrm{pH} 7.0$ ) added and stored in the refrigerator overnight after vortex. The blue supernatant was separated from the cell residue after centrifugation. C-phycocyanin calculations were determined using spectrophotometry-based methods on the absorbance ratio. The content of C-phycocyanin was calculated according to Setyoningrum and Azimatun Nur (2015) and Boussiba and Richmond (1979). Phycocyanin has a single visible absorbance maximum between 615 and $620 \mathrm{~nm}$.

$$
\text { \%Phycocyanin }=\left[A_{620} \times \mathrm{V} \times 100\right] /[7.3 \times \text { Sample }(\mathrm{mg}) \times \%
$$$$
\text { Dry matter] (Setyoningrum \& Azimatun Nur, 2015). }
$$

\section{3 is the extinction coefficient of C-PC at $620 \mathrm{~nm}$; V is} total volume; 100 represents $100 \%$.

The purity of C-PC preparations was evaluated based on the ratio between absorbencies from phycocyanobilin at $620 \mathrm{~nm}$ and aromatic amino acids in all proteins in the preparation at $280 \mathrm{~nm}$ (Antelo et al., 2010).

$$
\text { Purity ratio }=A_{620} / A_{280}
$$

The yield of the phycocyanin was calculated according to (Silveira et al., 2007).

[C-PC $(\mathrm{mg} / \mathrm{g}) *$ solvent volume $(\mathrm{mL})] /($ dry biomass $(\mathrm{g})]$

The concentration of the phycocyanin was calculated according to Bennett and Bogorad (1973).

$$
C-P C(\mathrm{mg} / \mathrm{mL})=[A(615)-0.474 * \mathrm{~A}(652)] / 5.34
$$

Protein was determined according to the Kjeldahl method (AOAC, 2000).

\section{DNA Protective Activity of Spirulina}

A pBR322 plasmid DNA (vivantis) was used to determine the DNA protection activity of Spirulina samples from damages caused by UV and oxidative stress. According to the method specified by Vanella et al. (2000) and imaging was performed on $1.25 \%$ agarose gel. Plasmid is a small, circular, double-stranded DNA molecule clearly showed the band on agarose gel electrophoresis. Pbr 322 DNA was often used DNA protective analysis that was optimized experimentally (Vanella et al., 2000; Kumar et al., 2001). Plasmid DNA was exposed to damage by applying $\mathrm{H}_{2} \mathrm{O}_{2}$ and UV in the presence of Spirulina in the component.

A $3.0 \mu \mathrm{l}$ pBR322 plasmid DNA (172ng. $\mu \mathrm{l}$ ) and $1 \mu \mathrm{l}$ $30 \% \mathrm{H}_{2} \mathrm{O}_{2}$ were placed in tubes. A light source was used AS a UV transilluminator (DNR-IS) device that generates light at $302 \mathrm{~nm}$ wavelength and $8000 \mu \mathrm{W} / \mathrm{cm}$ intensity at ambient temperature. After gel electrophoresis was conducted for 45 minutes, the photograph was obtained through imaging in the gel documentation system (DNRIS, Mini BISa Pro).

\section{Statistical Analysis}

Data were subjected to a one-way analysis of variance (ANOVA). LSD test was used to determine the difference between the groups. The statistical evaluation of the data was provided by Statgraphics Centurion XVI (Manugistics Incorporated, USA). The mean values obtained are given as "Mean \pm Standard Error". All tests were performed at a $95 \%$ confidence interval.

\section{Results}

The cell concentrate, optical density, $\mathrm{pH}$, and dry matter values in all groups were measured every three days a week during the trial (Figure 1, 2, 3, 4). The

Table 2. Phycoyanins and protein values of Arthrospira (Spirulina) platensis grown with Schlösser's and geothermal media.

\begin{tabular}{lccccc}
\hline & \% C-PC & Purity ratio $\mathrm{A}_{620} / \mathrm{A}_{280}$ & C-PC mg/mL & The yield of C-PC mg/g & $\%$ Protein \\
\hline \%100 Schlösser medium & $16.91 \pm 0.51$ & $4.43 \pm 0.28$ & $0.24 \pm 0.02$ & $54.26 \pm 1.5$ & $55.00 \pm 1.01$ \\
Geothermal medium \% 100 & $4.66 \pm 0.65$ & $1.22 \pm 0.45$ & $0.10 \pm 0.01$ & $18.25 \pm 0.58$ & $28.37 \pm 0.98$ \\
Geothermal medium \%50 & $8.08 \pm 0.74$ & $3.26 \pm 0.72$ & $0.11 \pm 0.01$ & $24.52 \pm 0.51$ & $38.35 \pm 0.88$ \\
\hline
\end{tabular}

Table 3. Bicarbonate cost for obtaining $1 \mathrm{~kg}$ Spirulina

\begin{tabular}{lcc}
\hline Spirulina Mediums & $\mathrm{HCO}_{3}\left(\mathrm{~kg} / \mathrm{m}^{3}\right)$ & Biomass $\mathrm{kg} / €$ \\
\hline Schlösser 100\% & 12.8 & 3 \\
Geothermal water 100\% & 0.28 & 0.07 \\
Geothermal water 50\% & 5.4 & 1.35 \\
\hline
\end{tabular}


highest protein, phycocyanin and dry biomass content among the groups were obtained with the Schlössser medium. ( $\leq \leq 0.05)$ (Table 2). In this experiment, the purity of the phycocyanin was achieved at 3.25 with $50 \%$ geothermal water. However, in the Schlösser medium, phycocyanin was obtained at an analytical purity of over 4. Schlösser medium is contained $13.6 \mathrm{~g} \mathrm{~L}^{-1}$ (Schlösser, 1994) of bicarbonate while the content Sanliurfa-Karaali in Turkey Geothermal Water $0.236 \mathrm{~g} \mathrm{~L}^{-1}$ (Çiftçi, 2015) comprising bicarbonate. In this research, with $50 \%$ geothermal water was obtained $38 \%$ protein, resulting in $8 \%$ phycocyanin (Table 2 ) and $1.27 \mathrm{~g} \mathrm{~L}^{-1}$ dry matter. In the group containing $100 \%$ geothermal nutrient medium, $48.35 \%$ protein was obtained, but the dry matter values $(p \leq 0.05)$ were lower than the other groups. However, when dry matter values were taken into consideration, less biomass was produced than in the other groups (Table 2). In the Schlösser medium, $55 \%$ protein and $1.75 \mathrm{~g} \mathrm{~L}^{-1}$ Spirulina were provided in $16 \%$ phycocyanin. In the cost analysis (Table 3), $5.4 \mathrm{~kg}$ of $\mathrm{HCO}_{3}$ was consumed to produce $1 \mathrm{~kg}$ Spirulina with $\% 50$ geothermal water, while in the control group, $1 \mathrm{~kg}$
Spirulina was obtained with $12.84 \mathrm{~kg} \mathrm{HCO}_{3}$. The highest phycocyanin concentration $\left(0.24 \mathrm{mg} \mathrm{mL}^{-1}\right)$ was received with the Schlösser medium. In the group containing 50\%

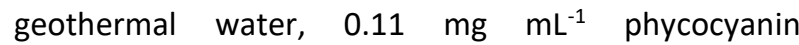
concentration was obtained. The phycocyanin yield of the Schlösser medium was received at $54 \mathrm{mg} \mathrm{g}^{-1}$, but geothermal groups reduced the phycocyanin yield.

In the study, the pBR322 plasmid DNA to detect the effects of the Spirulina samples in protecting the DNA against oxidative and UV induced damages. Three types of forms are seen in the plasmid DNA agarose gel imaging system. According to the separation state, these are Nicked DNA, Linear DNA, and Supercoiled DNA. The supercoiled structure is observed because only the plasmid loadings do not have DNA cleavage or opening. DNA protective activity is an indicator of this protective effect in band lustre up to the form of the band in evaluations. This study obtained band images by loading three different agoras gels. In Figure 5 (a), the DNA bands of Spirulina produced in the control groups and Schössler media were visualized. Figure 5 (b) was shown that the band obtained by using geothermal

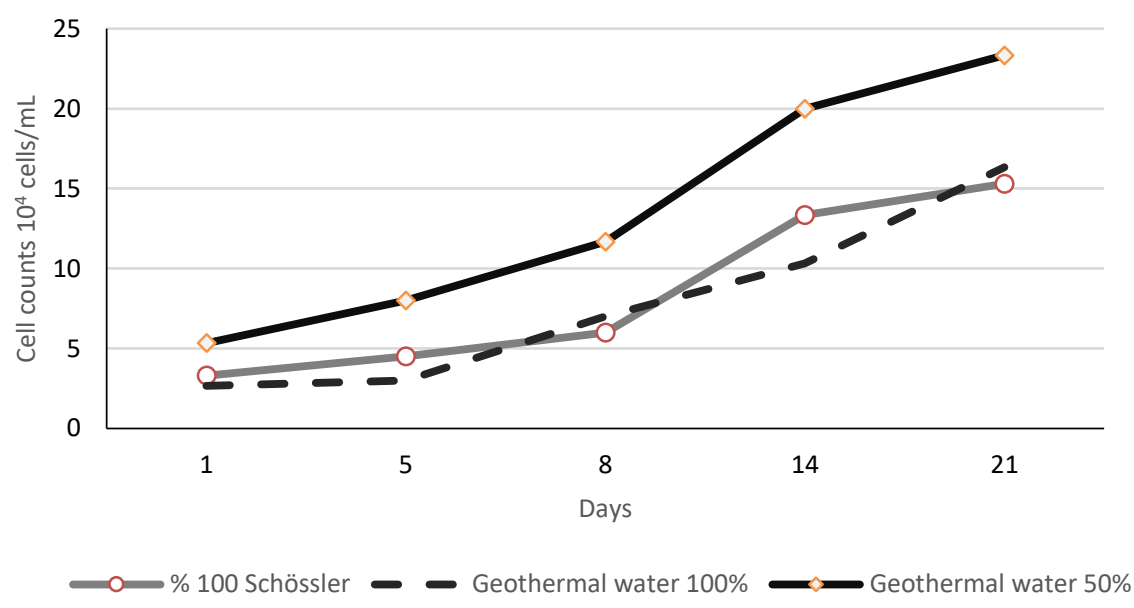

Figure 1. Cell concentration of Arthrospira (Spirulina) platensis grown in with Schlösser's and geothermal media.

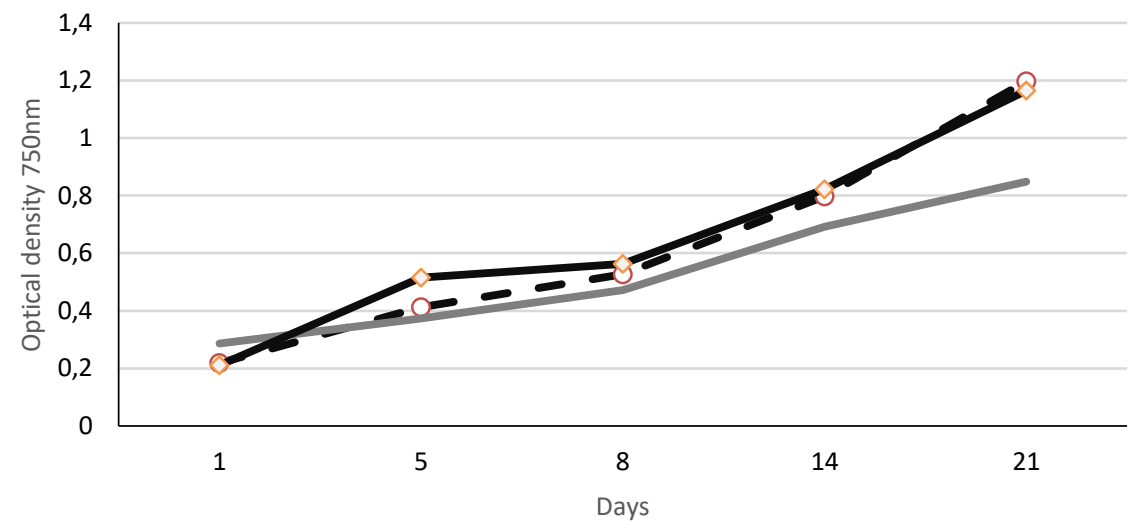

- $\% 100$ Schössler Geothermal water 100\% Geothermal water 50\%

Figure 2. Optical density of Arthrospira (Spirulina) platensis grown in with Schlösser's and geothermal media. 


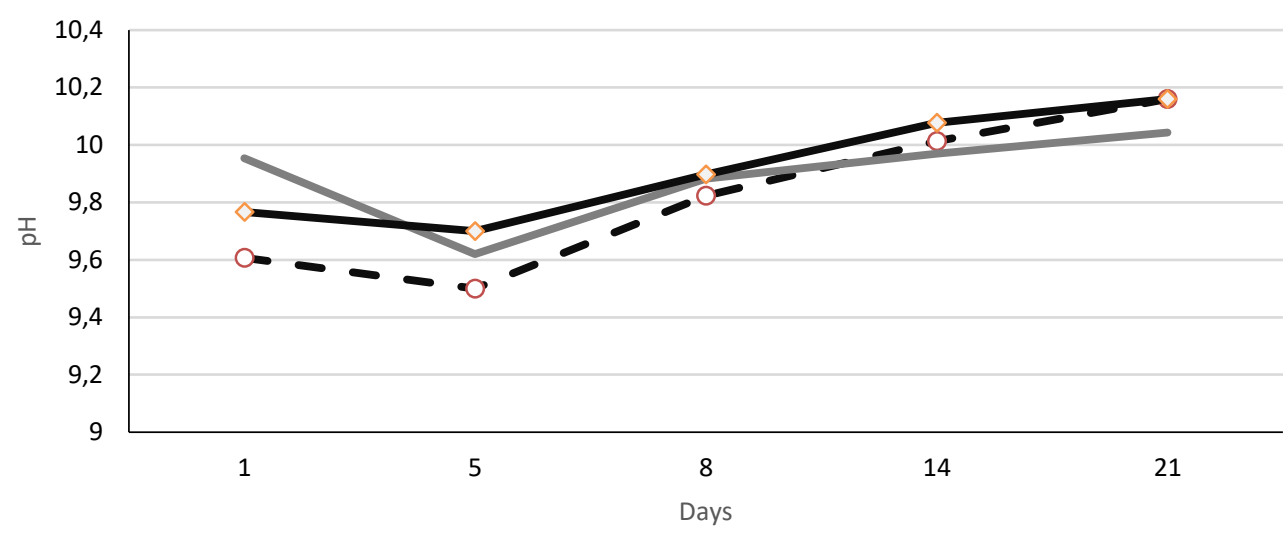

- $\% 100$ Schössler Geothermal water 100\% Geothermal water 50\%

Figure 3. $\mathrm{pH}$ of Arthrospira (Spirulina) platensis grown in with Schlösser's and geothermal media.

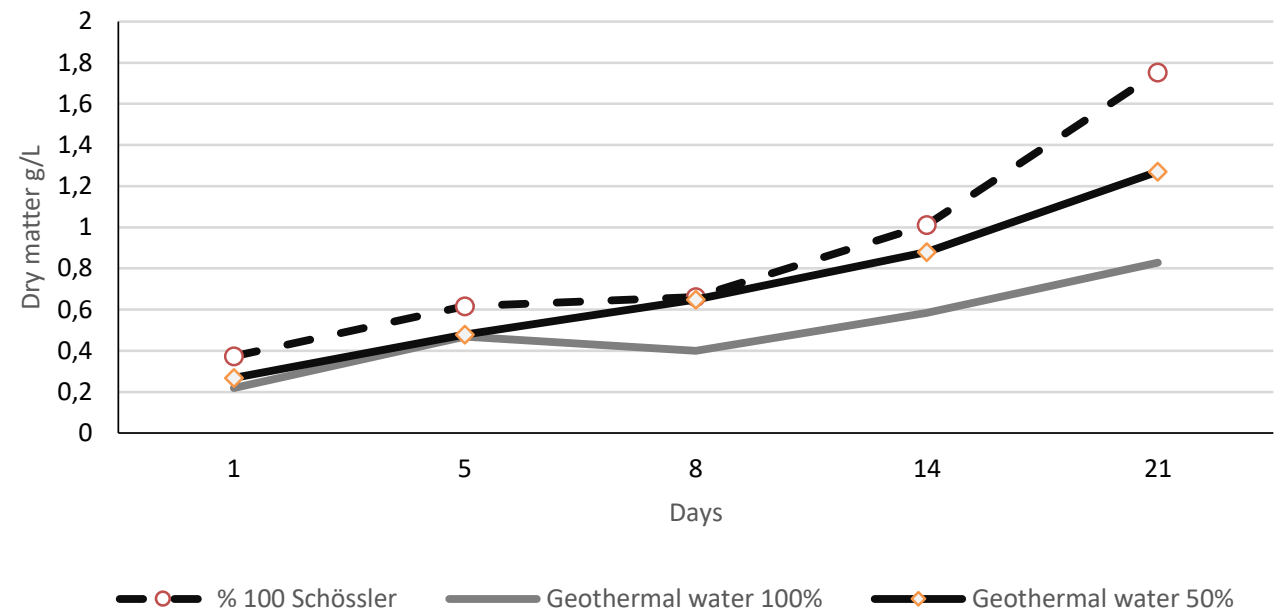

Figure 4. Dry matter of Arthrospira (Spirulina) platensis grown in with Schlösser's and geothermal media.

water at a rate of $50 \%$ and $100 \%$ is the band images. DNA protection activities of producing at Schlösser medium (code of A1) and control group (code of $\mathrm{K} 1$ and $\mathrm{K} 2$ ) compare with different ratios of geothermal water (\%50 A and \%100 A2). The Spirulina produced in the Shössler medium shows DNA protective activity compared to the control groups, as shown in Fig. 5 (a). When the DNA band results in Fig. 5 (b) was examined, it was found that the $A$ and $A 2$ had higher activity than the Schlösser medium (A1). When we compare the bands in Figures 5 (b), it was seen that sample A2 produced in $100 \%$ geothermal water gives a better band appearance compared to $50 \%$ geothermal water.

\section{Discussion}

The purity of the phycocyanin is determined by the ratio of the absorbance at $620 \mathrm{~nm}$ to the absorbance at $280 \mathrm{~nm}$ (A620/A280). The application area of the phycocyanin is determined according to the obtained purity ratio. According to this, it is accepted that phycocyanin has a purity ratio of 0.7 or more, suitable for food, 3.9 for reactive, and four or more for analytical purity (Kuddus et al., 2013)._In this research, phycocyanin purity was achieved over three in the $50 \%$ geothermal water and the Schlösser medium. These results have shown the idea that geothermal waters are attractive for phycocyanin production. Phycocyanin obtained from Spirulina is sold in international markets for \$200-1800 per $\mathrm{kg}$, depending on the degree of purity. Jespersen et al. (2005) reported that the ideal stability between the gardenia blues, phycocyanin (lina blue), and indigo blue pigments for use in food was provided by the phycocyanin._The phycocyanin content of the Schlössser medium (16\%) was higher than the $50 \%$ geothermal water $(8 \%)$ and the $100 \%$ geothermal water (4\%). There has been reported that the Spirulina dry weight may include between $10-20 \%$ of phycocyanin (Vonshak, 1997; Chaiklahan et al., 2011). Even if a minimum of $10 \%$ of phycocyanin is obtained with Spirulina, the cost of phycocyanin is on average 180 


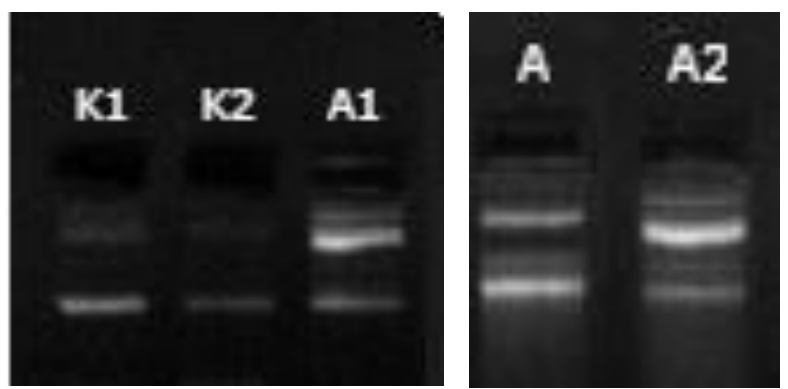

Figure 5 (a): Control and Shössler medium (b): \% 50 (A) and \%100 (A2) Şanlıurfa Karaali geotermal water

K1: Plasmid DNA $(3 \mu \mathrm{l})+$ distilled water $(6 \mu \mathrm{l})$

K2: Plasmid DNA $(3 \mu \mathrm{l})+\mathrm{UV}(5$ minutes $)+\mathrm{H}_{2} \mathrm{O}_{2}(1 \mu \mathrm{l})$

A1: Plasmid DNA $(3 \mu \mathrm{l})+\% 100$ shössler $40{ }^{\circ} \mathrm{C}(5 \mu \mathrm{l})+\mathrm{UV}(5$ minutes $)+\mathrm{H}_{2} \mathrm{O}_{2}(1 \mu \mathrm{l})$

A: Plasmid DNA $(3 \mu \mathrm{l})+\% 50$ Şanlıurfa Karaali geothermal water $40^{\circ} \mathrm{C}$ dried $(5 \mu \mathrm{l})+\mathrm{UV}(5$ minutes $)+\mathrm{H}_{2} \mathrm{O}_{2}(1 \mu \mathrm{l})$

A2: Plasmid DNA $(3 \mu \mathrm{l})+\% 100$ Şanlıurfa Karaali geothermal $(5 \mu \mathrm{l})+\mathrm{UV}(5$ minutes $)+\mathrm{H}_{2} \mathrm{O}_{2}(1 \mu \mathrm{l})$

$\mathrm{kg} / €$. The phycocyanin content of Spirulina varies depending on many factors. For instance, it is known that different light sources alter the C-PC productivity of Spirulina platensis (Prates et al., 2018) recommends a green LED to achieve maximum phycocyanin (126.39 $\mathrm{mg} / \mathrm{g}$ ). Ho et al. (2018) reported that the addition of $50 \%$ nitrate obtained $14 \%$ phycocyanin and $86.6 \mathrm{mg} \mathrm{L}^{-1}$ phycocyanin concentrate. The highest phycocyanin concentration (240 $\mathrm{mg} \mathrm{L}^{-1}$ ) was achieved with the Schlösser medium, while in the group containing $50 \%$ geothermal water, $110 \mathrm{mg} / \mathrm{L}$ phycocyanin was obtained. This result is higher than the findings of Ho et al. (2018), although it is lower than the value found by Prates et al. (2018). In the control group, $54 \mathrm{mg} / \mathrm{g}$ phycocyanin yield was obtained, but geothermal water more reduced the yield of phycocyanin. Further research should be carried out on this issue since light and temperature on the phycocyanin are affected.

The highest protein (55\%) and dry biomass (1.75 g L) content among the groups were obtained in the Schlössser medium. ( $p \leq 0.05)$. In this research, with $50 \%$ geothermal water was achieved $38 \%$ protein and $1.27 \mathrm{~g}$ L-1 dry matter. In the group containing $100 \%$ geothermal nutrient medium, $28.37 \%$ protein was obtained, but the dry matter values $(p \leq 0.05)$ were lower than the other groups. In Turkey, geothermal water obtained from the Armutlu region was evaluated for Spirulina production. In the summer period in the greenhouse, $1.286 \mathrm{~g}$. L-1 dry matter content and 59\% protein ratio were provided in $75 \%$ geothermal water substituted groups instead of Schlösser Spirulina medium in $500 \mathrm{~L}$ algal ponds (Guroy et al., 2018). In another research, geothermal water obtained from the Armutlu region was replaced with $20 \%$ distilled water, and the Spirulina medium was prepared. According to the results of studies examining the effects of different inoculation rates, the 1:6 inoculation rate provided the best development. In the group containing geothermal water, $48.42 \%$ protein and $22.48 \%$ phycocyanin content were detected, and it was reported that $61 \%$ protein was obtained with Schlösser medium (Guroy \& Guroy, 2017).
Geothermal energy, together with economic benefits in the heating of photobioreactors and greenhouses, also reduces algal biomass drying costs (Godlewska et al., 2015). Cost analysis has shown that geothermal waters may be a low-cost alternative in Spirulina production when dry matter values are considered. Macro and microelements in geothermal waters can reduce the cost of commercial compounds added to the water environment to prepare Spirulina media. Geothermal water can be used directly or substituting these nutrient mediums depending on mineral content to achieve optimal algal productivity.

Detailed studies have been conducted on various medicinal plants extracts that control oxidative DNA damage causing cancers (Bayil Oguzkan et al., 2016). DNA damage can arise from the harmful effects of UV rays leading to a destruction of the stratosphere layer and adverse effects on living organisms. Moreover, UV rays can cause serious diseases, including skin cancer and skin ageing. The topical application of both enzymatic and non-enzymatic skin antioxidants is a practical approach to protect the skin against the harmful effects of UV rays (Hitoshi, 2010). For this reason, the use of Spiruluna plantesis as alternative products of the healthcare sector, especially in cosmetics and medicine, should be assessed by testing the protective activity on DNA. In this study, Spirulina plantesis produced on geothermal water has been demonstrated to be an excellent protective activity, as shown in Fig. 5 (b). The literature also reported that it plays a critical role in antioxidants in eliminating the harmful effects of UV rays that cause DNA damage (André et al., 2017). Human skin has several mechanisms to reduce the detrimental impact of VIS (visible rays) and UV rays. However, high levels of exposure to UV rays can reduce the number of cellular antioxidants and ultimately lead to UV-induced oxidative DNA damage caused by reactive oxygen species (Tepe et al., 2011). In addition to UV rays, free radicals can cause DNA damage. Also, we have been demonstrated that how geothermal water affects Spirulina samples' DNA protective activities and 
antioxidant levels. Spriulina plantesis produced with different ratios of geothermal water has been the better properties to compare the Schlösser medium.

\section{Conclusion}

This study results have shown that geothermal waters can be used to grow Spirulina (Arthrospira) platensis and geothermal waters may be a low-cost alternative in Spirulina production when dry matter values are considered. Since the nutrient medium, light and temperature affect the Spirulina nutrient components and bioactive components, the investigations in this area should be increased.

\section{Ethical Statement}

Spirulina, used as an organism in this study, is a symbiotic, multicellular and filamentous blue-green microalga and is not subject to the experimental animal ethical committee review since it is not considered an experimental animal.

\section{Funding Information}

The authors received no specific funding for this work.

\section{Author Contribution}

BG: Investigation, Methodology, Conceptualizatio n, Writing -review and editing; SBO: Data Curation, Formal Analysis, and Writing -original draft; DG: Formal Analysis, Investigation, Writing -review and editing

\section{Conflict of Interest}

The authors declare that there were no conflicts of interest.

\section{Acknowledgements}

We would like to thank the district governor of Armutlu, Mr Uğur Sezer, the Mayor of Haliliye in Şanlıurfa, Mr Fevzi Demirkol, and the Mayor of Armutlu, Mr Mehmet Birkan, for their contributions and supports to the delivery of Şanlıurfa geothermal water to Algae Production Unit of Yalova University. A part of this study was presented 1st International Gap Agriculture and Livestock Congress 2018 Şanlıurfa, Turkey.

\section{References}

André, P. S., Natália, C. M., Natielen, J. S., Carlos, F., Martins, M., Camila, C., \& Machado, G. (2017). Sunlight damage to cellular DNA: Focus on oxidatively generated lesions. Free Radical Biology and Medicine, 107, 110-124.

Antelo, F. S., Anschau, A., Costa, J. A. V., \& Kalil, S. J. (2010). Extraction and purification of C-phycocyanin from
Spirulina platensis in conventional and integrated aqueous two-phase systems. Journal of the Brazilian Chemical Society, 21(5):921-926. doi:10.1590/s0103-50532010000500022.

AOAC, Official Methods of Analysis of AOAC. (2000). International (17th ed.). Arlington, VA: AOAC.

ayil, O. S., Guroy, B., Tonus, S. S., Guroy, D., \& Kılıc, H. I. (2018). The bioactive component and DNA protective capability of cultured Spirulina in Turkey (Marmara Region). Genetics of Aquatic Organisms, 1: 7-12.

Bennett, A., \& Bogorad, L. (1973). Complimentary Chromatic Adaptation in a Filamentous Blue Green Alga, The Journal of Cell Biology, 58 No:2 419.

Boussiba, S., \& Richmond, A. E. (1979). Isolation and characterization of phycocyanins from the blue-green alga Spirulina platensis. Archives of Microbiology, 120(2):155-159. doi:10.1007/BF00409102.

Capelli, B., \& Cysewski, G. R. (2010). Potential health benefits of Spirulina microalgae. Nutrafoods, 9:19-26. doi: 10.1007/BF03223332.

Chaiklahan, R., Chirasuwan, N., Loha, V., Tia, S., \& Bunnag, B. (2011). Separation and purification of phycocyanin from Spirulina sp. using a membrane process. Bioresour Technology, 102: 7159- 64.

Çiftçi, C. (2015). Karaali Village Monography. Institute of Social Sciences Geography Study. Master's Thesis. SanlıurfaTurkey.

de Jesus Raposo, M. F., de Morais, A. M. M. B., \& de Morais, R. M. S. C. (2016). Emergent sources of prebiotics: seaweeds and microalgae. Marine Drugs, 14, 27.

Delrue, F., Alaux, E., Moudjaoui, L., Gaignard, C., Fleury, G., Perilhou, A., Richaud, P., Petitjean, M., \& Sassi, J. F. (2017). Optimization of Arthrospira platensis (Spirulina) Growth: From Laboratory Scale to Pilot Scale. Fermentation, 3, 59.

Fan, X., Cui, Y., Zhang, R., \& Zhang, X. (2018). Purification and identification of anti-obesity peptides derived from Spirulina platensis. Journal of Functional Foods, 47, 350360.

Godlewska, K., Tomaszewska, B., Michalak, I., Bujakowski, W., \& Chojnacka, K. (2015). Prospects of geothermal water; Use in cultivation of Spirulina. Open Chemistry, 13: 12181227.

Gutteridge, J. M. C. \& Halliwell, B. (2000). Free Radicals and Antioxidants in the Year 2000. A Historical Look to the Future. Annals of the New York Academy of Sciences, 899, 136-147.

Guroy, B., \& Guroy, D. (2017). Geothermal Water (Armutlu) and Spirulina (Arthrospira) Platensis Production and Determination of the Content of C-Phycocyanin. Oral session presentation at the meeting of the 19. National Water Products Symposium, Sinop- Turkey.

Guroy, B., Guroy, D., Mantoglu, S., Karadal, O., \& Oguzkan, S. B. (2018). The Effect of the Geothermal Water on Protein Content of Spirulina in Greenhouse Condition" Oral session presentation at the meeting of the International Agricultural Science Congress, Van- Turkey.

Guroy, B., \& Guroy, D. (2018). Production of Spirulina platensis with Çankırı geothermal water. Oral session presentation at the meeting of the International Agricultural Science Congress, Van- Turkey.

Guroy, B. (2017). Effects of Spirulina fresh biomass or powder on the phycocyanin content and sensory properties of muffin. Oral session presentation at the meeting of the Aquaculture Europe, Dubrovnik - Croatia. 
Guroy, D., Guroy, B., Merrifield, D. L., Ergun, S., Tekinay, A. A. \& Yigit, M. (2011). Effect of dietary Ulva and Spirulina on weight loss and body composition of rainbow trout, Oncorhynchus mykiss (Walbaum), during a starvation period. Journal of Animal Physiology and Animal Nutrition, 95:320-327.

Hitoshi, M. (2010). Role of antioxidants in the skin: Anti-aging effects. The Journal of Dermatological Science, 58: 8590.

Ho, S. H., Liao, J. F, Chen, C., \& Chang, J. S. (2018). Combining light strategies with recycled medium to enhance the economic feasibility of phycocyanin production with Spirulina platensis. Bioresource Technology, 247, 669675.

Jespersen, L., Strømdahl, L.D., Olsen, K., \& Skibsted, L. H. (2005). Heat and light stability of three natural blue colorants for use in confectionery and beverages. European Food Research and Technology, 220, (3-4), 261-266.

Kuddus, M., Singh, P., Thomas, G., \& Al-Hazimi, A. (2013) Recent developments in production and biotechnological applications of C-phycocyanin. BioMed Research International, 742-859. doi:10.3109/1040841X.2012.678477.

Khafaga, A. F., \& El-Sayed, Y. S. (2018). Spirulina ameliorates methotrexate hepatotoxicity via antioxidant, immune stimulation, and proinflammatory cytokines and apoptotic proteins modulation. Life Sciences, 196, 9-17.

Kumar, S. S, Devasagayam, T. P. A, Jayashree, P., \& Kesavan, C. B. (2001). Mechanism of protection against radiation induced DNA damage in plasmid pBR322 byCaffeine. International Journal of Radiation Biology, 77, 617- 623.

Lakshmanan, R., Shukla, S., Alagarsamy, V., \& Purushothaman, C. (2013). Growth performance of Spirulina (Arthrospira) platensis in a low-cost medium: An assessment. Acta Biologica Indica. 2. 335-342.

Lazaro, N. M., Valdivia, V. B., Colín, M. F., \& Europa, E.C. (2018). Arthrospira maxima (Spirulina) and C-phycocyanin prevent the progression of chronic kidney disease and its cardiovascular complications. Journal of Functional Foods, 43, 37-43.

Lokapirnasari, W.P., Yulian, A.B., Legowoc, D., \& Agustono. (2016). The Effect of Spirulina as Feed Additive to Myocardial Necrosis and Leukocyte of Chicken with Avian Influenza (H5N1) Virus Infection. Procedia Chemistry, 18, 213-217.

Lucas, B. L., de Morais, M. G., Santosa, T. D., \& Vieira Costa, J. A. (2018). Spirulina for snack enrichment: Nutritional, physical and sensory evaluations. Volume 90, LWT, Pages 270-276.

Lund, J. \& Boyd, T. (2016). Direct Utilization of Geothermal Energy 2015 Worldwide Review. Geothermics, 60. 6693. 10.1016/j.geothermics.2015.11.004

Markou, G., Wang, L., Ye, J., \& Unc, A. (2018). Using agroindustrial wastes for the cultivation of microalgae and duckweeds: Contamination risks and biomass safety concerns. Biotechnology Advances, 36 (4), 1238-1254.

Moorhead, K., Capelli, B., \& Cysewski, C. R. (1993). Spirulina Nature's Superfood. Book. Cyanotech Corporation.

Mahmoud, M. M. A., El-Lamie, M. M. M., Kilany, O. E., \& Dessoukid, A. A. (2018). Spirulina (Arthrospira platensis) supplementation improves growth performance, feed utilization, immune response, and relieves oxidative stress in Nile tilapia (Oreochromis niloticus) challenged with Pseudomonas fluorescens. Fish \& Shellfish Immunology, 72, 291-300.

Prates, D. F., Radmann, E. M., Duarte, J. H., de Morais, M. G. \& Costa, J. A. V. (2018). Spirulina cultivated under different light emitting diodes: Enhanced cell growth and phycocyanin production. Bioresource Technology, 256, 38-43.

Paoletti, C., Pushparaj, B., \& Tomaselli, F. L. (1975). Ricerche Sulla Nutrizione Minerale di Spirulina platensis. In: Atti Cong. Naz. Italian Society of Microbiology, 17, Padova. 2, pp. 845-853.

Pelizer L. H., \& Moraes, O. I. (2014). A method to estimate the biomass of Spirulina platensis cultivated on a solid medium. Brazilian Journal of Microbiology, 45(3): 933936.

Radhakrishnan, S., Bhavan, P. S., Seenivasan, C., \& Muralisankar, T. (2017). Nutritional Profile of Spirulina platensis, Chlorella vulgaris and Azolla pinnata to Novel Protein Source for Aquaculture Feed Formulation. Austin Journal of Aquac Marine Biology, Volume 2 Issue 1.

Setyoningrum, T. M., \& Azimatun Nur, M. M. (2015). Optimization of Cphycocyanin production from $S$ platensis cultivated on mixotrophic condition by using response surface methodology. Biocatalysis and Agricultural Biotechnology, 4(4):603-607. doi: 10.1016/j.bcab.2015.09.008.

Silveira, S. T., Burkert, J. F. M., Costa, J. A. V., Burkert, C. A. V., \& Kalil, S. J. (2007). Optimization of Phycocyanin Extraction from Spirulina platensis Using Factorial Design. Bioresource Technology, 98, 1629-1634.

Sugiharto, S., Yudiarti, T., Isroli, I., \& Widiastuti, E. (2018). Effect of feeding duration of Spirulina platensis on growth performance, haematological parameters, intestinal microbial population and carcass traits of broiler chicks. South African Journal of Animal Science, 48 (No. 1).

Schlösser, U. G. (1994). SAG-Sammlung von Algen Kulturen at the University of Göttingen Catalogue of Strains. Botanica Acta, 107: 111 - 186

Xiong, J., Liu, S., Panac, Y., Zhangac, B., Chenac, X., \& Fanac, L. (2018). Combination of fish oil and ethanol extracts from Spirulina platensis inhibits the airway inflammation induced by ovalbumin in mice. Journal of Functional Foods, 40, 707-714.

Vanella, A., Russo, A., Acquaviva, R., Campisi, A., Giacomo, C.D., Sorrenti, V., \& Barcellona, M. L. (2000). Propionylcarnitine as superoxide scavenger, antioxidant, and DNA cleavage protector. Cell Biology and Toxicology, 16: 99104.

Vonshak, A. (1997). Spirulina platensis (Arthospira): Physiology, Cell Biology and Biotechnology. Taylor \& Francis, London.

Yu,W., Wen, G., Lin, H., Yang, Y., Huang, X., Zhou, C., Zhang, Z. Duan, Y., Huang, Z.,\&Li, T. (2018). Effects of dietary Spirulina platensis on growth performance, hematological and serum biochemical parameters, hepatic antioxidant status, immune responses and disease resistance of Coral trout Plectropomus leopardus (Lacepede, 1802). Fish \& Shellfish Immunology, 74, 649655.

Zarrouk, C. (1966). Contribution al'étuded'unecyanophycée: Influence de divers facteurs physiques et chimiquessur la croissance et la photosynthese de Spirulina maxima (Setch et Gardner) Geitler, University of Paris. 
Tepe, B., Degerli, S., Arslan, S., Malatyali, E., \& Sarikurkcu, C. (2011). Determination of chemicalprofile, antioxidant, DNA damage protection and anti-amoebic activities of Teucriumpolium and Stachysiberica. Fitoterapia, 82: 237-246. 